\title{
PELATIHAN PARADIGMA DAN METODE PEMBELAJARAN
}

\author{
Edy Subali \\ Enie Hendrajati
}

\begin{abstract}
Abstrak
Persoalan yang dihadapi dunia pendidikan kita di antaranya sikap pembelajar terhadap proses pembelajaran relatif kuang positif. Mereka tampaknya hanya bersekolah, belum belajar. Bersekolah hanyalah seperti mengikuti tahapan-tahapan menjalani kehidupan saja, layaknya jarum jam yang bergerak tanpa ruh.Rasa ingin bisanya (tujuan psikomotor) cenderung sangat rendah. Ditandai oleh takut mencoba, takut salah, takut malu jika tidak bisa. Seolah-olah salah itu tidak boleh, pertanda bodoh bahkan goblok. Akibat lanjutannya, kebiasaan yang cenderung terbentuk adalah mencari jalan pintas, seperti menyontek, mencontoh persis, kopi-paste, "bacem", dan membeli ke biro jasa skripsi. Bibit-bibit untuk membentuk manusia dengan karakter suka menerabas, tidak peka mutu, tidak disiplin murni bahkan watak hipokrit sudah tampak menggejala. Tidak bermental pegulat atau pengarum jeram. Bermental penerabas. Variabel yang menjadi penyebabnya tentu sangat kompleks. Jangan-jangan budaya seneoritas, feodalisme, santun ke atas telah ikut mengantar paradigma botol kosong yang harus diisi ke dalam dunia pendidikan. Guru dan sekolah layaknya penguasa yang "leluasa" membentuk, mencetak lulusan. Globalisasi menginspirasi elit pendidikan kita untuk memperbarui paradigma pembelajaran, yang berakibat pada perubahan kurikulum, silabus, rencana pelaksanaan pembelajaran (RPP), termasuk juga pendekatan dan metode pembelajarannya. Dengan paradigma pembelajaran bahwa siswa laksana butiran emas yang masih penuh lumpur maka prinsip yang perlu dijadikan kesadaran oleh para pendidik adalah bebaskan anakanak dari "penjajahan" sekolahan, termasuk oleh gurunya. Pendekatan penggalian dan pengembangan potensi (butiran emas) oleh dirinya sendiri secara konsistenharus ditanamkan dan digalakkan. Guru dan manajemen sekolah hanya memfasilitasi agar tercipta atmosfer pembelajaran yang menyenangkan sehingga sekolah dan ruang-ruang kelas laksana lahan subur yang di atasnya dapat tumbuh subur benih-benih unggul yang penuh potensi. Guru bukan mengisi atau mengajar, tapi mengasah, mengasuh, menyulut, menyadarkan, memakcomblangi. Iklim atau suasana pembelajaran harus menyenangkan. Berarti, (a) fasilitas pembelajaran di sekolah harus memadai, (b) jumlah siswa per kelas juga mempengaruhinya; semakin banyak jumlahnya semakin sulit mengendalikan dan membuat suasana pembelajaran menyenangkan; (c) gaya komunikasi verbal dan nonverbal oleh guru, terutama dalam proses pembelajaran harus sirkuler bukan linier, harus demokratis bukan otoriter-doktriner, harus menyenangkan bukan membosankan dan juga harus bersifat keibuan atau kebapakan bukan kelaki-lakian, keras, kaku dan menakutkan.
\end{abstract}

Kata kunci: persoalan pembelajaran, tujuan pembelajaran, paradigma pembelajaran, iklim pembelajaran, metode pembelajaran

Pada tanggal 7 sampai dengan 8 September 2012, dimulai pukul 08.00 sampai pukul 16.00, kami (10 dosen) dari Unit Penyelenggara Matakuliah Sosial Humaniora (UPM Soshum) ITS mengadakan pengabdian kepada masyarakat. Tempat atau lokasinya di BPPNFI Regional IV, Jalan Gebang Putih Surabaya. Bentuk pengabdiannya adalah pelatihan peningkatan mutu pembelajaran bagi

jsh Jurnal Sosial Humaniora, Vol 5 No.2, November 2012 
guru-guru MTs Swasta di Surabaya. Guru MTs yang mengikuti pelatihan tersebut berjumlah 30 orang. Mereka berasal dari 6 sekolah MTs, yaitu MTs Nurul Islam, Kapasbaru V/3 Surabaya, MTs Miftahul Ulum, Sidonipah VII/1c Surabaya, MTs Al-Ikhlas, Dr. Soetomo 103 Surabaya, MTs At Tauhid Sidoresmo dalam II/37 Surabaya, MTs Ittaqu, Mananggal IV/7 Surabaya dan MTs Nurul Salam Bulak Rukem 1, No 17 Surabaya. Di sekolah tersebut mereka mengajar bahasa Indonesia, mengajar Agama Islam, PPKN. Materi kegiatan pelatihan tersebut meliputi: manajemen mutu terpadu, metode pembelajaran, pengembangan bahan pembelajaran, media pembelajaran, silabus dan rencana pelaksanaan pembelajaran dan evaluasi pembelajaran. Pada hari keduanya dilakukan workshop pengembangan silabus, RPP (rencana pelaksanaan pembelajaran) dan bahan ajar, serta presentasi hasil workshop oleh masing-masing kelompok.

Visi MTs (1) prima dalam prestasi berlandaskan keimanan dan ketaqwaan kepada Tuhan, (2) pribadi unggul dalam moral dan intelektual berlandaskan AlQuran dan Sunnah Rasul yang mampu menghadapi tantangan global. Visi adalah fantasi yang diciptakan secara sadar, sebuah angan-angan atau prinsip-prinsip atau nilai pokok dalam suatu organisasi. Visi adalah realita yang belum terjadi dan sumbernya bukan dari kepala, tetapi dari hati. Dengan visi MTs tersebut makaseharusnya akan memberi inspirasi komitmen bagi para pengelolanya, termasuk guru-gurunya.

\section{Permasalahan Proses Pembelajaran}

Menarik untuk kita renungkan beberapa pernyataan Pak Daniel Mohammad Rosyid (2008:13) dalam tulisannya yang berjudul "Makar melalui Pendidikan Murahan". Pernyataannya adalah "Menunda mendidik warga negara dengan pendidikan yang terbaik sama saja dengan secara sengaja merusak masa depan mereka dan masa depan bangsa ini. Warga yang tidak terdidik dan terlatih dengan baik akan menjadi sumber masalah yang ajeg menggerogoti upaya-upaya pembangunan di segala bidang. Warga semacam ini menjadi mesin bernilai kurang, bukan mesin nilai tambah yang menciptakan kesejahteraan dan kemakmuran.” Dengan demikian, apapun kegiatan pengabdian atau pelatihan 
yang kita lakukan terhadap aspek-aspek terkait dengan pendidikan maka tetap membahagiakan karena terasa ikut andil mendidik warga negara yang bernilai tambah.

Kegiatan pengabdian ini dilakukan antara lain untuk membantu guru-guru MTs mengidentifikasi persoalan-persoalan yang menjadi kendala dalam meningkatkan mutu proses pembelajaran, khususnya dalam upaya mencapai tujuan belajar. Oleh karena itu, kami menganggap penting mengawali pelatihan tersebut dengan menanyakan dan mendiskusikan beberapa hal yang cenderung menjadi kendala untuk mencapai tujuan pembelajaran, baik tujuan afeksi, kognisi maupun psikomotor. Hal tersebut penting karena segala aspek dalam proses pembelajaran diarahkan untuk mencapai tujuan pembelajaran. Pertanyaan dan jawabannya dapat dibaca pada paparan berikut ini.

Apa yang menyebabkan siswa tidak atau kurang gigih belajar? Pertanyaan untuk menjaring permasalahan yang menjadi kendala dalam memproses pencapaian tujuan afeksi. Jawaban pertanyaan tersebut dianggap penting diketahui agar (1) minat, komitmen atau sikap pembelajar terhadap proses pembelajaran di kelas dapat diidentifikasi, (2) pendekatan dan metode pembelajaran yang hendak ditrapkan di kelas sesuai dengan persoalan tersebut. Berdasarkan informasidari guru MTs peserta pelatihan dapat diketahui bahwa persoalan kegigihan atau sikap pembelajar yang jamak dihadapi para guru adalah seperti berikut: (1) tidak adamotivasi belajar yang gigih, terasa tidak ada kegairahan, bahkan tampak terasa bahwa bersekolah adalah beban; (2) mereka tampaknya hanya bersekolah, belum belajar, (3) tujuan untuk membuat mereka suka atau bersikap positif (tujuan afeksi) terhadap pembelajaran sulit tercapai, (4) akibat lanjutannya adalah mereka masuk kelas, mendengarkan, dan tidak suka bertanya apalagi berdiskusi dan berdebat. Jika cepat pulang dan tidak ada tugas rumah dari guru sangat senang sekali; (5) jika diberi tugas "yang penting tugas selesai", tanpa perlu menganggap penting prinsip originalitas, aktualitas dan manfaatnya; (6) catatan di kelas tidak banyak, kecuali didikte, (6) indikasi bahwa pembelajar kurang bersikap positif, tujuan afeksi belum tercapai. Bapak dan Ibu guru (peserta pelatihan) sangat penting untuk merenungkan paparan yang saya 
kutip dari buku "Quantum Teaching" berikut ini dengan harapan dapat mengilhami dan memberi inspirasi. "Peran emosi dalam belajar. Memperhatikan emosi siswa dapat membantu Anda mempercepat pembelajaran mereka. Memahami emosi mereka juga dapat membuat pembelajaran lebih berarti dan permanen. Ingatlah sejenak sewaktu Anda di perguruan tinggi dahulu. Ingatkah Anda, di kelas mana Anda sangat berminat pada mata kuliahnya? Informasi mana yang lebih Anda ingat? Informasi dari dosen yang Anda sukai, atau dosen yang tidak anda sukai? Betul! Dosen yang Anda sukai menciptakan dalam diri Anda suatu ikatan emosional terhadap belajar, yang mematri mata kuliah tersebut dalam ingatan Anda. Penelitian otak semakin menunjukkan adanya hubungan antara keterlibatan emosi, memori jangka panjang dan belajar. Ketika otak menerima tekanan dan ancaman, kapasitas saraf untuk berfikir rasional mengecil. Otak “dibajak secara emosional” menjadi mode bertempur atau kabur dan beroprerasi pada tingkat bertahan hidup. Ketersediaan hubungan dan kegiatan saraf benarbenar berkurang atau sangat mengecil dalam situasi ini, dan otak tidak dapat mengakses Higher Order Thinking Skill” (2001:21-22).“Keberanian memiliki kecerdasan dan keajaiban di dalamnya" kata Goethe. Hasil riset Jack Canfield, pakar masalah kepercayaan diri melaporkan hasil penelitiannya bahwa anak-anak, rata-rata menerima 460 komentar negatif atau kritik dan 75 komentar positif atau dukungan setiap hari (Bobbi De Porter, 2000:25). Jadi, emosi positif dalam proses pembelajaran sangat berpengaruh terhadap hasil belajar.

Bagaimana rasa ingin tahu siswa MTs ketika Bapak atau Ibu mendampingi kegiatan belajar mereka di kelas? Jawaban dari para guru peserta pelatihan (semua cenderung menyetujuinya) adalah (1) rendah, ditandai oleh siswa jarang bertanya apalagi membaca, (2) ketika masih balita "hasrat ingin tahu dan ingin bisanya" tinggi, tapi setelah bersekolah menjadi "kempes", (3) bersekolah seperti hanya mengikuti tahapan-tahapan menjalani kehidupan saja, layaknya jarum jam yang bergerak tanpa ruh, (4) sekolah "mengempeskan". Menjajah? Penjara? Karena lebih dominan linier-indoktrinasi. Rasa sakit atau hukuman jasmani dalam belajar dianggap komponen penting pembelajaran? Sangat maskulinisasi? (5) belajar membaca, menulis dan berhitung harus seirama atau dipadukan dengan ketukan 
tongkat kayu; (6) indikasi sangat behavioristik-mekanistik; (7) indikasi tujuan kognisi sulit dicapai. Berikut ini paparan yang saya kutip dari bukunya Bapak Mulyasa (2008:40-41) yang berjudul "Menjadi Guru Profesional Menciptakan Pembelajaran Kreatif dan menyenangkan”. Saya berharap kutipan berikut ini dapat menginspirasi Bapak dan Ibu guru.

"Guru dapat diibaratkan sebagai pembimbing perjalanan (journey), yang berdasarkan pengetahuan dan pengalamannya bertanggung jawab atas kelancaran perjalanan itu. Dalam hal ini, istilah perjalanan tidak hanya menyangkut fisik tetapi juga perjalanan mental, emosional, kreatifitas, moral, dan spiritual yang lebih dalam dan kompleks. Sebagai pembimbing, guru harus merumuskan tujuan secara jelas, menetapkan waktu perjalanan, menetapkan jalan yang harus ditempuh, menggunakan petunjuk perjalanan, serta menilai kelancarannya sesuai dengan kebutuhan dan kemampuan peserta didik. Semua itu dilakukan berdasarkan kerja sama yang baik dengan peserta didik, tetapi guru memberikan pengaruh utama dalam setiap aspek perjalanan. Sebagai pembimbing, guru memiliki berbagai hak dan tanggung jawab dalam setiap perjalanan yang direncanakan dan dilaksanakannya."

Bagaimana rasa ingin bisa siswa MTs ketika Bapak atau Ibu mendampingi kegiatan belajar mereka di kelas? Jawaban para guru MTs peserta pelatihan kurang-lebih maksudnya seperti: (1) rasa ingin bisa bagi mereka sangat rendah, ditandai oleh takut mencoba, takut salah, takut atau malu jika tidak bisa, kemudian dimarahi, atau dapat tekanan fisik-psikologis; (2) sementara upaya untuk berlatih secara tekun, ulet, konsisten dalam waktu yang relatif lama sangat sulit terbentuk; (3) akibat lanjutannya, kebiasaan yang cenderung terbentuk adalah dengan mencari terobosan, jalan pintas, seperti menyontek, mencontoh persis, kopi-paste, "bacem", meminjam dan menyuruh; bibit-bibit untuk membentuk manusia dengan watak atau karakter seperti suka menerabas, tidak peka mutu, tidak disiplin murni bahkan watak hipokrit sudah tampak menggejala;

(4) kebiasaan tersebut cenderung bisa terus dipelihara, menjadi karakternya, gaya hidupnya dan akan terbawa hingga dewasa; (5) kesadaran mendidik diri degan tekun, ulet, semangat dan konsisten dalam waktu sekian kali, sekian lama sangat rendah. Padahal untuk 
bisa menulis dan membaca

"Ini ibu Budi" ketika di SD dulu perlu waktu bertahun-tahun; (6) ketahanan mentalnya rendah. Tidak bermental pegulat atau pengarum jeram, tapi justru bermental penerabas; (7) tujuan psikomotor sulit bisa dicapai secara optimal.

Terkait dengan upaya mencapai tujuan psikomotor maka berikut ini saya kutipkan pandangan Dave Meir (2003:145) dalam bukunya yang berjudul "The Accelerated Learning Handbook Panduan Kreatif Merancang Program Pendidikan dan Pelatihan." Setelah Bapak dan Ibu guru membaca, memahami dan menyerap nilai gizinya diharapkan dapat mewarnai kegiatan pembelajaran di kelas.

"Pengetahuan bukanlah sesuatu yang Anda serap, melainkan sesuatu yang Anda ciptakan. Tahap pelatihan (integrasi) merupakan intisari Accelerated Learning. Tanpa tahap penting ini, tidak ada pembelajaran. Tahap ini dalam siklus pembelajaran berpengaruh terhadap 70\% (atau lebih) pengalaman belajar secara keseluruhan. Dalam tahap inilah pembelajaran yang sebenarnya berlangsung. Bagaimanapun, apa yang dipikirkan dan dikatakan serta dilakukan pembelajarlah yang menciptakan pembelajaran, bukan apa yang dipikirkan, dikatakan dan dilakukan instruktur. Peranan instruktur hanyalah memprakarsai proses belajar, lalu menyingkir. Dengan kata lain, tugas instruktur adalah menyusun konteks tempat pembelajar dapat menciptakan isi yang bermakna mengenai materi belajar yang sedang dibahas. Peranan instruktur adalah mengajak pembelajar berfikir, berkata dan berbuat. Menangani materi belajar yang baru dengan cara yang dapat membantu mereka memadukannya ke dalam struktur pengetahuan, makna dan keterampilan internal yang sudah tertanam di dalamdiri. Fasilitator yang selalu mengawasi dan menyuapi pembelajar merupakan ancaman serius terhadap proses belajar"

Setelah lulus dari studinya, apa profesi yang cenderung diminatinya? Jawabannya beragam, misalnya: (1) ingin jadi pegawai negeri sipil, (2) ingin jadi pengusaha, (3) ingin jadi karyawan perusahaan, (4) tidak ada gambaran ingin jadi apa, (5) terserah nasib, (6) yang penting bekerja, (7) mereka sudah biasa 
bermimpi, tetapi entah kalau mimpi yang identik dengan visi. Pilihan 4, 5, 6, 7 cenderung lebih banyak. Pertanyaannya adalah siapa yang punya andil dan perlu bertanggung jawab terhadap gaya hidup tersebut?

\section{Paradigma dan Prinsip yang Perlu Dijadikan Kesadaran}

Materi yang disampaikan kepada guru-guru peserta pelatihan, antara lain berupa paradigma dan prinsip-prinsip pemberdayaan proses pembelajaran, yang pada hakekatnya merupakan proses membangun tanggung jawab untuk menjadi terbiasa mendidik dirinya sendiri secara aktif dan mandiri sepanjang hayat. Paradigma dan prinnsip yang disampaikan kepada guru diupayakan menjadi landasan yang dapat mewarnai tugas profesionalnya sebagai pendidik generasi penerus dan penentu masa depan bangsa iniadalah bagaimana Bapak dan Ibu guru memaknai, memandang atau memposisikan siswa-siswinya, apakah mereka (1) dipandang seperti kertas putih yang akan dilukis oleh Bapak-Ibu, sama seperti botol kosong yang akan diisiatau sebaliknya, (2) memandang murid-murid laksana butiran emas dalam lumpur yang butuh perlakuan tertentu dari Bapak-Ibu guru agar potensi yang laksana butiran emas tadi dapat berbentuk emas yang bernilai. Bagaimanapun juga pilihan cara pandangoleh guru terhadap siswasiswinya sangat mempengaruhi proses pembelajaran, terutama terhadap metode pembelajaran yang akan digunakan guru.

Pada umumnya cara pandang guru terhadap murid-muridnya yang selama ini medominasi dan mewarnai proses pembelajaran adalah cara pandang yang pertama. Murid adalah botol yang perlu diisi ilmu oleh guru, atau kertas putih yang tidak punya warna mental apa pun. Gurulah yang memiliki kebebasan (tentu sesuai dengan kurikulum 1994) apakah kertas putih akan diwarnai merah, kuning atau hijau. Perdekatan behavioristik-mekanistik mendominasi proses pembelajaran. Akibatnya, pembelajarannya berpusat pada guru; belajar adalah menerima pengetahuan, bersifat pasif-reseptif, linier-indoktrinatif; pengetahuan dipandang sebagai barang jadi yang ada di luar manusia atau guru dan siswa. Gurulah yang bertugas mentransfernya ke murid atau siswa-siswinya. Alangkah sayangnya jika pemahaman seperti tersebut benar-benar masih ada dan adanya 
dominan. Hal ini karena manusia pada dasarnya bernaluri ingin bebas berekspresi, bebas menjadi subyek pembelajaran. Bukan justru yang sebaliknya. Akan tetapi, jika model pembelajaran yang bersifat pasif-reseptif dan linier-indoktrinatif terus menggejala dalam kenyataan maka akan berpeluang terciptanya manusia yang kurang peka mutu, mudah mengambil jalan pintas dan hipokrit. Oleh karena itu tidak berlebihan apabila Paulo Freire (2004:176) dalam bukunya "Politik Pendidikan Kebudayaan, Kekuasaan dan Pembebabasan" memaparkan bahwa "Pendidikan yang membebaskan merupakan proses di mana pendidik mengkondisikan siswa untuk mengenal dan mengungkap kehidupan yang senyatanya secara kritis. Pendidikan yang membelenggu bersifat preskriptif, sedangkan yang membebaskan bersifat dialogis. Pendidikan yang membelenggu merupakan transfer pengetahuan, sedangkan yang membebaskan merupakan upaya untuk memperoleh pengatahuan dan menjadi proses transformasi yang diuji dalam kehidupan nyata".

Mengingat kondisi global yang semakin memperluas dan memperketat persaingan, persyaratan kerja dan perubahan orientasi maka perubahan kompetensi lulusan merupakan tuntutan yang tidak bisa dihindari. Globalisasi menuntut perubahan kompetensi lulusan dan ujung-ujungnya juga perlu diikuti perubahan paradigma pengetahuan, belajar dan mengajar, sekaligus perubahan kurikulumnya. Kurikulum 1994 yang cenderung berbasis isi berubah menjadi Kurikulum Berbasis Kompetensi dan kemudian Kurikulum Tingkat Satuan Pendidikan (KTSP). Semangat perubahan kurikulum yang diinspirasi oleh globalisasi perlu terus disosialisasikan kepada para pendidik, termasuk guru-guru MTs swasta di Surabaya.

Dengan paradigma pembelajaran yang baru, yakni siswa laksana butiran emas yang masih penuh lumpur maka prinsip yang perlu dijadikan kesadaran oleh para pendidik atau guru adalah: (1) bebaskan anak-anak dari "penjajahan" sekolahan, termasuk oleh gurunya. Pendekatan penggalian dan pengembangan potensi (butiran emas) oleh dirinya sendiri secara konsisten, alamiah dan menyenangkan harus ditanamkan dan digalakkan Guru dan manajemen sekolah hanya memberikan fasilitas yang memungkinkan terciptanya suasana atau 
atmosfer pembelajaran. Atmosfer tersebutakan berfungsi seperti lahan subur yang di atasnya dapat tumbuh subur benih-benih unggul yang penuh potensi; (2) jangan menumpulkan, tapi menajamkan. Berarti, biasakan dengan metode mengajar yang bersifat mengasah, mengasuh dengan iklim atau atmorfer suasana yang sejuk, tenang, nyaman, terbuka, kekeluargaan. Jadi, harus menggunakan pendekatan keibuan dan kebapakan; (3) jangan mengempeskan, tapi mengembangkan potensinya sesuai dengan minat, bakat dan kecenderung-kecenderungan tertentu yang tampak akan diminati dan disukai pembelajar (kecerdasan ganda).

Apa saja yang perlu digali, diasah dan dikembangkan? Apakah setiap manusia sama-sama memiliki potensi tahu, bisa dan suka apa saja, seperti halnya setiap manusia bisa membaca, menulis, berhitung dan mancal sepeda, tanpa kecuali? Dengan kata lain, pada dasarnya tidak ada manusia bodoh? Yang ada hanyalah manusia lemah, yakni setiap manusia cenderung ingin yang baik dan bermutu, tanpa perlu proses lama dan berat? Pertanyaan-pertanyaan tersebut sengaja disodorkan kepada guru peserta pelatihan dengan harapan menjadikan bahan renungan dan kemudian menjadi prinsip-prinsip yang mewarnai pelaksanaan proses pembelajaran di tempat kerjanya.

Anak didik juga perlu dididik menjadi dirinya sendiri yang original. Bukan yang palsu, yang tidak punya otonomi diri karena terbiasa didekte dan didoktrin, bahkan lebih tepat digunakan istilah dijajah, kemudian terbiasa memakai topeng. Jadi, budaya purak-purak, tidak jelas bentuknya, tidak "kesatria", manusia semu harus dihilangkan. Lembaga pendidikan punya kewajiban untuk membentuk manusia original.

\section{Implikasi Cara Pandang "Dalam Diri Setiap Pembelajar Ada Potensi Butiran Emas"}

Implikasi paradigma pembelajaran yang baru tersebut, terutama terhadap:

(1) metode pembelajaran. Guru bukan mengisi atau mengajar, tapi mengasah, mengasuh, menyulut, memotifasi, menyadarkan, memakcomblangi. Guru bertugas mengasah. Maksudnya, menggosok, memotivasi, mendorongsiswa supaya memiliki kesadaran dan tanggung jawab sendiri untuk mengasah 
pikiran, perasan atau emosi, sikap, bakat dan tindakan yang nantinya akan diperagakan di masyarakat dan tempat kerjanya. Guru bertugas mengasuh. Maksudnya adalah membimbing, melatih, merawat, memimpin dan mendewasakan atau mematangkan mental peserta didik. Guru bertugas menyulut. Artinya, menyalakan, membakar api semangat, menstimulasinya agar ada antusiasme dalam mendidik dirinya. Disarankan agar siswa terbiasa bertanggung jawab sendiri atas kualitas akademik dan emosionalnya; tidak terbiasa bergantung dan memasrahkannya kepada pihak lain, termasuk ke guru dan sekolahnya. Guru bertugas menyadarkan siswanya. Artinya, membuat mereka siuman, membangunkan, menginsyafkan dengan cara membuatnya tahu dan mengerti benar tentang pentingnya pendidikan, pengetahuan, ketrampilan dan kepribadian yang baik sebagai bekal membangun hidupnya atau masa depannya. Guru bertugas memakcomblangi. Maksudnya, guru menjadi fasilitator, penghubung utama agar siswanya mencintai, menyayangi dan berjodoh dengan pembelajaran. Belajar adalah kebutuhan pokok, tanpa belajar terasa ada yang kurang dan tidak lengkap. Sama seperti jika tidak makan, tidak minum, terasa lapar dan haus. Belajar menjadi nalurinya.

(2) Iklim atau suasana pembelajaran harus menyenangkan. Berarti, (a) fasilitas pembelajaran di sekolah harus memadai, (b)jumlah siswa per kelas juga mempengaruhi; semakin banyak jumlahnya semakin sulit mengendalikan dan membuat suasana pembelajaran menyenangkan; (c) gaya komunikasi verbal dan nonverbal oleh guru, terutama dalam proses pembelajaran harus sirkuler bukan linier, harus demokratis bukan otoriter-doktriner, menyenangkan bukan membosankan dan juga harus bersifat keibuan atau kebapakan bukan kelakilakian, keras, kaku dan menakutkan.

(3) Pengetahuan, sikap dan keterampilan tidak berada di luar diri, tapi sudah ada di dalam diri. Gurulah yang bertugas memfasilitasi agar siswanya bertanggung jawab untuk menggali dan mengeluarkannya sendiri. Hanya dirinya sendirilah yang bisa mengeluarkannya. Pembelajar lebih banyak 
belajar dari apa yang mereka katakan atau lakukan sendiri daripada apa yang dikatakan (orang lain) atas mereka (Win Wenger, 2003:28).

(4) Materi ajar bukan tujuan, tapi hanya berposisi sebagai bahan kajian yang akan menstimulasi pembelajar untuk mencapai tujuan pembelajaran. Materi ajar hanya semacam kendaraan yang berpenumpang tujuan untuk diantarkan kepembelajar.

(5) Pembelajaran aktif dan mandiri. Artinya, guru hanya membantu, memfasilitasi,. menyulut, memakcomblangi agar anak didik bisa mendidikdirinya sendiri secara aktif . Mendidik diri hanya mengandalkan dan menggantungkan pada pihak di luar diri (guru atau sekolah) biasanya kurang optimal hasilnya. Belajar akti merupakan fungsi interaksi antara individu dan situasi di sekitarnya yang diarahkan oleh tujuan belajar. Interaksi yang terus menerus akan menimbulkan pengalaman-pengalaman dan keinginan untuk memahami sesuatu yang baru, yang belum dipahami atau yang belum dialami. Belajar aktif ditandai bukan hanya melalui keaktifan mahasiswa yang belajar secara fisik, namun juga keaktifan mental. Justru keaktifan mental merupakan hal yang sangat penting dan utama dalam belajar aktif dibandingkan keaktifan fisik. Kemampuan belajar mandiri merupakan tujuan akhir dari belajar aktif (Paulina Pannen dkk, 1997: 2-3).

(6) Tidak ada orang bodoh, tidak ada yang tidak bisa, bahkan tidak ada orang jahat; yang ada hanya orang lemah (tidak sabar, ingin cepat walau tidak tepat) dan dari kelemahan itu kebodohan dan kejahatan masuk. Cara pandang seperti tersebut sangat penting bagi para pendidik karena akan dapat berpeluang besar memperlakukan anak didik dan proses pembelajaran secara positif dan optimis. Pendidik tidak akan gegabah menggunakan kata-kata bermuatan emosi negatif terhadap anak didik dalam proses pembelajaran. Seperti apa pun keadaan dan tingkah laku anak didik akan disikapinya secara optimis dan positif. Jika terpaksa harus jelas dan tegas atau bahkan menggunakan kata kasar maka perlu terukur dan proporsional. Sebuah tugas guru atau pendidik yang tidak mudah. 
(7) Hati-hati dengan kata lulus apalagi tamat karena akan menjadi pemicu berhenti belajar. Pada umumnya, setelah pembelajar lulus atau menamatkan studinya dari suatu jenjang pendidikan maka kata yang biasa digunakan adalah kata tamat. Kata tersebut bermakna berakhir, selesai, habis, khatam, mati. Kata selesai berarti putus, tidak berhubungan lagi karena sudah jadi atau sudah rampung. Jadi kata tamat atau lulus tersebut sebenarnya berkonotasi kurang mendidik.

\section{Kesimpulan}

Pendidik, termasuk guru-guru MTs swasta di Surabaya perlu terus diajak berdiskusi dan saling berbagi pengalaman (baca ikut pelatihan) tentang profesi keguruan masa kini dan masa depan. Informasi kepadanya tentang globalisasi dan pengaruhnya terhadap tuntutan perubahan figur sumber daya manusia masa depan sangatlah perlu. Bagaimanapun juga setiap lembaga pendidikan merupakan “dapur” yang menjadi tempat mengolah dan mamasak manusia muda. Harapannya tentu hasil olahan, yaitu lulusan atau alumsi yang penuh gizi dan dapat memberi gizi kepada orang lain, lingkungan sekitar dan kehidupan alam semesta ini. Untuk memenuhinya maka kurikulum, silabus dan rencana pelaksanaan pembelajaran yang merupakan daftar menu masakan atau makanan dan daftar teknis, pendekatan, strategi, metode mengoperasionalkannya di kelas atau sekolah perlu menyesuaikan diri dengan perkembangan jamannya yang sudah mengglobal. Demikian pula dengan guru-gurunya. Kurikulum, silabus dan rencana pelaksanaan pembelajaran berubah karena harus menyesuaikan diri dengan globalisasi, akan tetapi jika guru-guru atau pendidiknya tidak mengikuti dan menyesuaikan diri dengan perubahan tersebut maka cara memasak atau mengolahnya atau metode pembelajarannya di kelas-kelas tetap yang konvensional: guru bertugas mengisi, mengajar bukan menyulut, mengasah dan membuat mereka menjadi pembelajar aktif dan mandiri.

Dengan prinsip saling berbagi, saling ingat-mengingatkan, misalnya dengan pelatihan ini maka apa yang diharapkan kita semua sebagai pendidik akan tercapai. Meskipun demikian kesadaran akan proses, akan sejarah yang cenderung 
bergerak secara tahap demi tahap tetap harus menjadi prinsip hidup kita bersama. Dengan demikian maka optimisme, harapan positif dan masa depan bersama yang membahagiakan, Insyaallah akan tercapai.

\section{Daftar Pustaka}

De Porter, Bobi dkk. 2000. Quantum Learning Membiasakan Belajar Nyaman dan Menyenangkan. Bandung: Kaifa

De Porter, Bobi dkk. 2001. Quantum Teaching Mempraktikkan Quantum Learning di Ruang-Ruang Kelas. Bandung: Kaifa

Meier, Dave. 2003. The Accelerated Learning Hanbook Panduan Kreatif \& Efektif Merancang Program Pendidikan dan Pelatihan. Bandung: Kaifa

Mohammad Rosyid, Daniel. 2008. Pendidikan Nasional di Era reformasi Mau Kemana? Surabaya: Penerbit SIC.

Mulyasa, E. 2008. Menjadi Guru Profesional menciptakan Pembelajaran Kreatif dan Menyenangkan. Bandung: PT Remaja Rosdakarya

Pannen, Paulina dkk. 1997. Belajar aktif dan Mandiri. Mengajar di Perguruan Tinggi. Bagian Dua Program Applied Approach. Pusat Antar Universitas untuk Peningkatan dan Pengembangan Aktivitas Instruksional Direktorat Jenderal Pendidikan Tinggi Departemen Pendidikan dan Kebudayaan

Wenger, Win. 2003. Beyond Memadukan Quantum Teaching dan Learning. Bandung: Yayasan Nuansa Cendekia 
